\title{
FAKTOR-FAKTOR YANG MEMPENGARUHI HOLDING PERIOD SAHAM
}

\author{
Tiara Novia Fatrin', Yudhistira Ardana ${ }^{2}$, Wulandari ${ }^{2}$ \\ ${ }^{1}$ Manajemen, IIB Darmajaya \\ ${ }^{2}$ Sistem Informasi, STMIK Pringsewu \\ noviafatrin.tiara@gmail.com, ardanayudhistira@gmail.com,wulan@gmail.com
}

\begin{abstract}
Abstrak-Saham merupakan investasi yang banyak dipilih oleh investor karena mampu memberikan tingkat keuntungan yang menarik. Holding period merupakan periode yang menunjukkan panjangnya jangka waktu antara pembeli dan waktu penjualan saham yang dilakukan oleh investor. Penelitian ini bertujuan untuk mengetahui faktor-faktor yang mempengaruhi holding period saham secara parsial pada perusahaan yang terdaftar ke dalam indeks LQ45. Metode pada penelitian ini menggunakan metode deskriptif,dengan teknik pengambilan sampel menggunakan purposive sampling dan diperoleh 21 perusahaan sebagai sampel penelitian. Hasil penelitian menunjukkan market value dan volume perdagangan secara parsial berpengaruh signifikan terhadap holding period saham dengan nilai $t_{\text {hitung }}>t_{\text {tabel }}$ dan nilai sig lebih kecil dari 0,05 (sig < 0,05) yaitu sebesar 0,000 dan 0,005, sedangkan bid-ask spread, variance return dan dividen payout ratio secara parsial tidak berpengaruh signifikan terhadap holding period saham dengan nilai $t_{\text {hitung }}<t_{\text {tabel }}$ dan nilai sig lebih besar dari 0,05 (sig $>0,05$ ) yaitu sebesar 0,414, 0,706 dan 0,673. Nilai Adjusted.R.Square $\left(\mathrm{R}^{2}\right)$ sebesar 0,381 atau 38,1\% menunjukan bahwa bid-ask spread, market value, volume perdagangan, variance return, dividen payout ratio mampu menjelaskan variabel holding period saham sebesar $38,1 \%$, sedangkan sisanya $61,9 \%$ dijelaskan oleh variabel lain diluar penelitian.
\end{abstract}

Kata kunci: Holding Period, Bid-Ask Spread, Market Value, Trading Volume, Variance Return, Dividend Payout Ratio.

\begin{abstract}
Stocks are an investment that many investors choose because they are able to provide an attractive rate of return. Holding period is a period that indicates the length of this study was to determine the factors that affected the holding period of shares partially on the companies listed into to LQ45 index. This study used a descriptive method, with the purposive sampling technique and it obtained 21 companies as the research sample. The result of the research showed that the market value and the trading volume were partially significant to the holding period of stock with $t_{- \text {count }}>t_{- \text {table }}$ and sig value was smaller than 0,05 (sig < 0,05) that was 0,000 and 0,005, while the bid-ask spread, variance return, and dividend payout ratio partially had no significant effect on the holding period of stock with the value of $t_{- \text {count }}<t_{\text {-table }}$ and the sig value was greater than 0,05 (sig > 0,05) that was equal to 0,414, 0,706, and 0,673. The value of the adjusted $r$ square $\left(R^{2}\right)$ of 0,381 or $38,1 \%$ indicated the the bid-ask spread, the market value, the trading volume, the variance return, the dividend payout ratio could explain the holding period of $38,1 \%$, while the remaining $61,9 \%$ was explained by other variables outside the study.
\end{abstract}

Keywords: Holding Period, Bid-Ask Spread, Market Value, Trading Volume, Variance Return, Dividend Payout Ratio.

\section{PENDAHULUAN}

\section{Latar Belakang}

Banyaknya investasi yang dilakukan oleh para pelaku ekonomi saat ini sudah cukup berkembang, mulai dari investasi pada sektor rill maupun pada sektor financial. Hal seperti yang dituliskan oleh Wibowo (2008) dalam Nabila (2012) menyatakan bahwa dalam melakukan penelitian terhadap investasi cukup banyak tergantung pilihan investasi yang akan kita lakukan [1]. Investasi adalah langkah awal dalam kegiatan ekonomi.

Pasar modal merupakan sarana yang paling tepat selain perbankan dalam memobilisasi dana masyarakat guna membiayai dana pembangunan. Selain itu, pasar modal memiliki beberapa daya tarik sendiri dalam suatu Negara baik dalam hal likuiditas maupun efisiensi, oleh karena itu peranan pasar modal memiliki dua fungsi sekaligus yaitu fungsi ekonomi dan fungsi keuangan dimana pasar modal menyediakan wahana atau fasilitas yang mempertemukan 
dua kepentingan, yaitu pihak yang kelebihan (investor) dan pihak yang membutuhkan dana (issuer). Indeks LQ45 adalah salah satu indeks di Bursa Efek Indonesia (BEI), di mana indeks tersebut diperoleh dari perhitungan 45 emiten dengan diseleksi melalui beberapa kriteria seperti penilaian atas likuiditas.

Fenomena mengenai perilaku holding period yang terjadi pada perusahaan UNVR yaitu bulan Juni selama 314 hari tahun 2014, hal ini terbukti bahwa aset yang memiliki spread yang lebih besar akan menghasilkan expected return yang lebih tinggi dimana spread yang besar akan mempengaruhi frekuensi perdagangan, diketahui perusahaan Unilever Indonesia Tbk. memiliki jumlah saham beredar sebanyak 7,630,000,000 dan volume perdagangan sebanyak 33,894,000 hal ini menunjukkan bahwa volume transaksi perdagangan saham serta jumlah saham beredar yang tidak terlalu tinggi diperdagangkan pada bulan Juni sehingga perusahaan belum mampu memberikan keuntungan dari harga saham yang diperjualbelikan, salah satu alasan investor menahan saham yang dimilikinya dikarenakan nilai perusahaan tinggi akan menghasilkan kinerja yang baik untuk perusahaan sehingga akan menghasilkan laba usaha serta harga saham yang tinggi, bagi investor jangka panjang menjual saham tidak menjadi masalah yang paling utama, karena return utama dari investasinya adalah dividen. Investor akan terus menahan saham yang dimilikinya selama mungkin selama emiten yang menerbitkan saham tersebut masih memiliki prospek usaha yang menguntungkan. Hal ini yang membuat investor menahan sahamnya dalam waktu yang panjang.

\section{Rumusan Masalah}

Berdasarkan latar belakang masalah, perlu adanya identifikasi masalah penelitian agar penelitian yang dilaksanakan memiliki ruang lingkup yang jelas. Terdapat beberapa masalah yang dapat diidentifikasikan, yaitu:

a. Bagaimana pengaruh Bid-Ask Spread terhadap Holding Period pada perusahaan yang terdaftar di indeks LQ45?

b. Bagaimana pengaruh Market Value terhadap Holding Period pada perusahaan yang terdaftar di indeks LQ45?

c. Bagaimana pengaruh Variance Return terhadap Holding Period pada perusahaan yang terdaftar di indeks LQ45?

d. Bagaimana pengaruh Volume perdagangan terhadap Holding Period pada perusahaan yang terdaftar di indeks LQ45?

e. Bagaimana pengaruh Dividen Payout Ratio terhadap Holding Period pada perusahaan yang terdaftar di indeks LQ45?

\section{Tujuan Penelitian}

Untuk mengukur dan menganalisis secara parsial pengaruh Bid-Ask Spread, Market Value, Variance Return, Volume Perdagangan dan Diveiden Payout Ratio terhadap Holding Period pada perusahaan yang terdaftar di indeks LQ45.

\section{Manfaat Penelitian}

a. Bagi Akademik

Adanya penelitian ini diharapkan bermanfaat bagi mahasiswa/i, dalam rangka meningkatkan pengetahuan dan dapat digunakan oleh pembaca sebagai referensi untuk penelitian selanjutnya khusunya dibidang manajemen keuangan.

b. Bagi Investor

Penelitian ini diharapkan dapat memberikan informasi tentang lamanya atau waktu yang baik dalam menaham saham, sehinga dapat memperoleh keuntungan sesuai yang diharapkan.

c. Bagi Pembaca

Penelitian ini diharapkan mampu menjadi dasar atau acuan untuk penelitian selanjutnya yang lebih baik dan semakin reliabel.

\section{LANDASAN TEORI}

\section{Investasi}

Investasi dapat diartikan sebagai komitmen atas sejumlah dana atau sumber daya lainnya yang dilakukan pada saat ini, dengan tujuan memperoleh sejumlah keuntungan di masa mendatang (Tandelilin, 2010 dalam Afiffudin, 2014) [2]. Dalam berinvestasi, investor tidak tahu dengan pasti hasil yang akan diperolehnya dari investasi yang dilakukannya. Dalam keadaan seperti ini, investor menghadapi resiko investasi, investor hanya dapat memperkirakan hasil dan resiko 
yang akan diperoleh di masa depan.

\section{Teori Sinyal (Signaling Theory)}

Signaling theory menjelaskan mengapa perusahaan mempunyai dorongan untuk memberikan informasi laporan keuangan pada pihak eksternal. Dorongan perusahaan untuk memberikan informasi karena terdapat asimetri informasi anatara pihak perusahaan dan pihak luar karena perusahaan mengetahui lebih banyak mengenai perusahaan dan prospek yang akan datang daripada pihak luar. Hubungan teori sinyal dengan penelitian ini menunjukan bahwa holding period saham sering dianggap sebagai sinyal bagi investor dalam menilai baik buruknya perusahaan, hal ini disebabkan karena dimana investor melakukan holding period saham dapat membawa pengaruh terhadap harga saham perusahaan.

\section{Holding Period}

Menurut Jones (1996) dalam Ratnasari et al. (2014), holding period adalah rata-rata panjangnya waktu investor menahan saham perusahaan selama jangka waktu atau periode tertentu [3]. Holding period dihitung dengan rumus:

$$
\text { Holding period }=\frac{\text { Jumlah Saham Beredar }}{\text { Volume transaksi perdagangan }}
$$

\section{Bid-Ask Spread}

Bid-Ask Spread diartikan sebagai selisih antara harga beli tertinggi dari suatu saham dengan harga jual terendahnya, Wisayang (2011) [4].

$$
\text { spread }_{\text {it }}=\left[\sum_{t=1}^{n} \frac{A s k_{i t}-B i d_{i t}}{\left(A s k_{i t}+B i d_{i t}\right) / 2}\right] / N
$$

Keterangan:

Spread it $=$ Rata-rata bid-ask spread saham perusahaan i selama tahun $\mathrm{t}$

$N=$ Jumlah hari transaksi saham perusahaan i selama tahun $\mathrm{t}$

Ask it = Harga jual terendah yang menyebabkan investor setuju untuk menjual saham perusahaan i pada hari $\mathrm{t}$ $\begin{aligned} \text { Bid it }= & \text { Harga beli tertinggi yang } \\ & \text { menyebabkan investor } \\ & \text { setuju untuk membeli saham } \\ & \text { perusahaan i pada hari t }\end{aligned}$

\section{Market Value}

Market value adalah nilai yang berlaku di pasar sebagai suatu akibat dari perdagangan jual beli saham dalam priode tertentu, Jogiyanto (2000) dalam Ratnasari et al. (2014) market value adalah nilai pasar ekuitas pemegang saham yang merupakan pencerminan realitas keadaan ekuitas pemegang saham yang sebenarnya [5]. Perhitungan market value ditunjukan dengan rumus:

$M V_{i t}=$ harga saham ${ }_{i t} \times$ jumlah saham beredar ${ }_{i t}$

Keterangan:

MVit

= Rata-rata market value saham perusahaan i selama tahun $\mathrm{t}$

Harga saham it = Harga saham perusahaan i selama tahun $\mathrm{t}$

Saham beredar it $=$ Jumlah saham perusahaan i yang beredar selama tahun $\mathrm{t}$

\section{Volume Perdagangan}

Volume perdaganganadalahjumlah saham atau surat berharga yang diperdagangkan di pasar modal selama periode yang telah ditentukan yaitu per hari. Menurut Raharjdo (2004) dalam Paramita (2014) menyatakan volume perdagangan saham yaitu rata-rata banyaknya jumlah saham yang diperdagangkan pertahun [6]. Besarnya variabel volume perdagangan dengan mengamati kegiatan perdagangan saham yang dapat dilihat melalui indikator aktivitas volume perdagangan (Trading Volume Activity/TVA).

\section{Variance Return}

Variance Return saham perusahaan adalah ukuran langsung dari volatilitas saham perusahaan yang merupakan proksi dari resiko perusahaan. Menurut Atkins dan Dyl (1997) dalam Arma (2013) volatilitas perusahaan yang tinggi mengindikasikan asimetri yang lebih besar yang menyebabkan volume 
perdagangan yang lebih tinggi dan holding period yang lebih pendek [7]. Variance return dirumuskan sebagai berikut:

$$
\sigma_{i}^{2}=\sqrt{\frac{\sum_{t=1}^{n}\left(X_{i}-\bar{X}\right)^{2}}{n-1}}
$$

Keterangan:

$\sigma_{\text {it }}=$ standart deviasi

$\mathrm{X}_{\mathrm{i}}=$ return saham perusahaan $\mathrm{i}$

$\bar{x}=$ rata-rata return saham

$\mathrm{N}=$ jumlah data return saham

\section{Dividen Payout Ratio}

Dividen Payout Ratio yaitu persentase dividen yang dibagikan kepada pemegang saham dari laba bersih setelah pajak. Husnan (1998) dalam Maulina (2009) menyatakan jumlah dividen-dividen yang telah dibayar pada tahun tersebut dibagi dengan laba per lembar saham pada akhir tahun [8].

$$
D P R=\frac{\text { Dividen per share }}{\text { Earning per share }} \times 100 \%
$$

Keterangan:

$$
\begin{aligned}
& \text { DPR = Rasio pembayaran dividen } \\
& \text { DPS = Dividen per saham } \\
& \text { EPS }=\text { Laba per saham }
\end{aligned}
$$

\section{METODE PENELITIAN/EKSPERI- MEN}

\section{Populasi Dan Sample}

Populasi dalam penelitian ini adalah perusahaan yang terdaftar di indeks LQ45. Jumlah sample yang digunakan dalam penelitian ini adalah perusahaan yang terdaftar di indeks LQ45 melakukan holding period tahun 2014-2016. Teknik pengambilan sampel yang digunakan dalam penelitian ini adalah metode purposive sampling. Purposive sampling adalah teknik untuk menentukan sampel penelitian dengan beberapa pertimbangan yang bertujuan agar data yang diperoleh lebih refresentatif. Berdasarkan Kriteria pengambilan sampel didapatkan 21 perusahaan yang terdaftar di indeks LQ45 selama tiga tahun berturut-turut.

\section{Teknik Analisis Data}

Teknik analisis kuantitatif, yaitu analisis data dengan mengadakan perhitunganperhitungan yang relevan terhadap masalah yang dianalisis dengan mengunakan alat bantu SPSS 17.0 untuk dapat mempercepat proses analisis.

\section{UJI PRASYARAT DATA}

\section{Uji Normalitas}

Uji normalitas data bertujuan untu menguji apakah dalam suatu model regresi linier variabel terikat dan variabel bebas keduanya mempunyai distribusi normal

atau tidak. Model regresi yang baik adalah yang digunakan dalam uji normalitas adalah uji kolmogrov-Smirnov. Pengujian normalitas dilakukan dengan melihat nilai 2-tailed significant. Jika data memiliki hasil perhitungan dengan tingkat signifikansi lebih dari 0,05 atau (Sig) $>5 \%$ maka dapat disimpulakan bahwa Ha diterima, sehingga dapat dikatakan data tersebut berdistribusi normal.

\section{Uji Multikolineritas}

Uji multikolineritas bertujuan untuk menguji apakah model regresi ditemukan kolerasi antar variabel bebas. Metode untuk menguji adanya multikolineritas ini dapat dilihat dari tolerance value atau variance inflation factor (VIF). Kriteria yang digunakan adalah:

a. Jika nilai VIF di sekitar angka 1-10 maka dikatakan tidak terdapat masalah multikolineritas.

b. Jika nilai VIF di bawah angka 1-10 maka dikatakan terdapat masalah multikolineritas.

c. Jika nilai Tolerance $\geq 0,10$ maka dikatakan tidak terdapat masalah multikolineritas.

\section{Uji Autokorelasi}

Deteksi autokorelasi pada data time series dapat melalui uji Durbin-Watson. Nilai 
uji Durbin-Watson dibandingkan dengan nilai Durbin-Watson dengan tabel Durbin-Watson untuk mengetahui keberadaan korelasi positif atau negatif. Jika data terletak antara 2 dan 4 (untuk taraf signifikasi 5\%) maka tidak terjadi autokorelasi, tetapi jika data berada dibawah 2 dan 4 maka terjadi autokorelasi.

\section{Uji Heterokedastisitas}

Uji heterokedastisitas dilakukan untuk mengetahui apakah sebuah model regresi terjadi ketidaksamaan varians dari residual suatu pengamatan ke pengamatan lain. Jika varians dari residual suatu pengamatan ke pengamatan lain tetap, disebut homoskedastisitas. Model regresi yang baik tidak terjadi heterokedastisitas, yaitu dengan menggunakan model seperti glesjer test. Jika probabilitasnya di atas tingkat kepercayaan $(\rho>0,05)$, maka dapat disimpulkan model regresi tidak mengandung heterokeastisitas dan sebaliknya apabila dibawah signifikan ( $\rho$ $<0,05)$ berati terjadi heterokedastisitas.

\section{Analisis Regresi Berganda}

Teknik analisis data yang dilakukan dalam penelitian ini adalah analisis regresi berganda. Analisis regresi berganda adalah teknik statistik melalui koefisien parameter untuk mengetahui besarnya pengaruh variabel independen terhadap variabel dependen.

\section{UJI HIPOTESIS}

\section{Uji Parsial (Uji Statistik t)}

Uji Parsial atau biasa disebut uji $t$ merupakan uji yang dilakukan dalam mengetahui pengaruh dari masing-masing variabel, yaitu variabel independen (bebas) yang terdiri dari bid ask spread $\left(\mathrm{X}_{1}\right)$, Market Value $\left(\mathrm{X}_{2}\right)$, Variance Return $\left(\mathrm{X}_{3}\right)$, Volume perdagangan $\left(\mathrm{X}_{4}\right)$, Dividen Payout Ratio $\left(\mathrm{X}_{5}\right)$. Pada uji nilai $t$ hitung akan dibandingkan dengan tabel $t$, apabila t hitung lebih besar dari t tabel maka Ha diterima, dan sebalikanya. Pengujian ini dilakukan dengan tingkat kepercayaan $95 \%$ dan derajat kebabasan (alpha) 5\% dengan $d f=(\mathrm{n}-\mathrm{k})$.

\section{Koefisien Determinasi $\left(\mathbf{R}^{2}\right)$}

Nilai koefisien determinasi $\left(\mathrm{R}^{2}\right)$ digunakan untuk mengukur seberapa jauh kemampuan model dalam menerangkan variasi variabel dependen. Nilai koefisien determinasi $\left(\mathrm{R}^{2}\right)$ adalah antara 0 (nol) dan 1 (satu), dimana nilai $\mathrm{R}^{2}$ yang kecil atau mendekati 0 (nol) berarti kemampuan variabel-variabel independen dalam menjelaskan variasi variabel dependen amat terbatas, namun jika nilai $\mathrm{R}^{2}$ yang besar atau mendekati satu berarti variabel-variabel independen memberikan hampir semua informasi yang dibutuhkan untuk memprediksi variasi variabel dependen.

$$
Y=\alpha+\beta_{1} X_{1}+\beta_{2} X_{2}+\beta_{3} X_{3}+\beta_{4} X_{4}+\beta_{5} X_{5}+e
$$

\section{HASIL DAN PEMBAHASAN}

Tabel 1. Deskriptif Variabel Penelitian

\begin{tabular}{lrrrrrr}
\hline & \multicolumn{1}{c}{$\begin{array}{c}\text { Bid-Ask } \\
\text { Spread }\end{array}$} & Market Value & $\begin{array}{c}\text { Volume } \\
\text { Perdagangan }\end{array}$ & $\begin{array}{c}\text { Variance } \\
\text { Return }\end{array}$ & $\begin{array}{c}\text { Dividen } \\
\text { Payout Ratio }\end{array}$ & $\begin{array}{c}\text { Holding } \\
\text { Period }\end{array}$ \\
\hline N & Valid & 75 & 75 & 75 & 75 & 75 \\
Missing & 0 & 0 & 0 & 0 & 0 \\
Mean & .14513 & $1.40250 \mathrm{E} 14$ & $3.06836 \mathrm{E} 9$ & .33181 & .35469 & 14.45 \\
Std. Deviation & .109327 & $1.192531 \mathrm{E} 14$ & $5.259390 \mathrm{E} 9$ & .557496 & .258435 & 14.578 \\
Minimum & .010 & $2.995 \mathrm{E} 12$ & $1.883 \mathrm{E} 8$ & .013 & .000 & .0 \\
Maximum & .978 & $4.012 \mathrm{E} 14$ & $3.591 \mathrm{E} 10$ & 4.294 & 1.000 & 60 \\
\hline
\end{tabular}

Tabel 1 menunjukkan bahwa besarnya bid-ask spread perusahaan yang tercatat ke dalam indeks LQ45 dari 75 sampel berkisar antara 0,010 sampai 0,978 dengan rata-rata 14,14513 pada standar deviasi 0,109327 . 
Menunjukkan bahwa nilai besarnya market value perusahaan yang tercatat ke dalam indeks LQ45 dari 75 sampel berkisar antara 2.995 sampai 4,012 dengan rata-rata 1,40250 pada standar deviasi 1.19253.

Menunjukkan bahwa nilai besarnya volume perdagangan perusahaan yang tercatat ke dalam indeks LQ45 dari 75 sampel berkisar antara 1,883 sampai 3,591 dengan rata-rata 3,068 pada standar deviasi 5,259.
Menunjukkan bahwa nilai besarnya variance return perusahaan yang tercatat ke dalam indeks LQ45 dari 75 sampel berkisar antara 0,013 sampai 4,294 dengan rata-rata 0,33181 pada standar deviasi 0,557496.

Menunjukkan bahwa nilai besarnya dividen payout ratio perusahaan yang tercatat ke dalam indeks LQ45 dari 75 sampel berkisar antara 0,000 sampai 1,000 dengan rata-rata 0,35469 pada standar deviasi 0,258435 .

\section{Analisis Regresi Linier Berganda}

Tabel 2. Hasil Analisis Regresi Linier Berganda

\begin{tabular}{lcccc}
\hline & B & Std.Error & $\mathbf{t}_{\text {hitung }}$ & Sig \\
\hline Constanta & 14,375 & 4,467 & 3,218 & 0.002 \\
Bid-Ask Spread $\left(\mathrm{X}_{1}\right)$ & $-16,109$ & 19,559 & $-0,824$ & 0,414 \\
Market Value $\left(\mathrm{X}_{2}\right)$ & $3,755 \mathrm{E}-14$ & 0,000 & 2,469 & 0,000 \\
Volume Perdagangan $\left(\mathrm{X}_{3}\right)$ & $-8,320 \mathrm{E}-10$ & 0,000 & 2,627 & 0,005 \\
Variance Return $\left(\mathrm{X}_{4}\right)$ & 2,602 & 3,685 & 0,706 & 0,483 \\
Dividen Payout Ratio $\left(\mathrm{X}_{5}\right)$ & $-2,823$ & 6,656 & $-0,424$ & 0,673 \\
\hline R & \multicolumn{5}{c}{0,381} \\
\hline R Square & \multicolumn{5}{c}{0,488} \\
\hline
\end{tabular}

Hasil tersebut dapat ditulis dalam model persamaan regresi sebagai berikut:

$$
Y=14,375-16,109 X_{1}+3,755 X_{2}-8,320 X_{3}+2,602 X_{4}-2,823 X_{5}+\varepsilon
$$

1. Nilai konstanta sebesar 14,275 artinya jika variabel bid-ask spread, market value, volume perdagangan, variance return dan dividen payout ratio bernilai 0 , maka akan menaikkan holding period saham sebesar 14,375.

2. Nilai koefisien bid-ask spread adalah -16,109 artinya setiap kenaikan bid-ask spread akan menurunkan holding period saham sebesar 16,109.

3. Nilai koefisien market value adalah 3,755 artinya setiap kenaikan market value akan menaikkan holding period saham sebesar 3,755 .

4. Nilai koefisien volume perdagangan adalah $-8,320$ artinya setiap kenaikan volume perdagangan akan menurunkan holding period saham sebesar 8,320.

5. Nilai koefisien variance return adalah 2,602 artinya setiap kenaikan variance return akan menaikkan holding period saham sebesar 2,602.

6. Nilai koefisien dividen payout ratio adalah $-2,823$ artinya setiap kenaikan dividen payout ratio akan menurunkan holding period saham sebesar 2,823.

7.

\section{Pembahasan}

Pengaruh bid-ask spread terhadap holding period saham

Hasil uji t untuk variabel bid-ask spread memiliki nilai t hitung sebesar $-0,824$ dan diperoleh nilai signifikansi sebesar 0,414. Nilai signifikansi lebih besar dari tingkat signifikansinya $(0,414>0,05)$. Hasil penelitian ini dapat disimpulkan bahwa bid-ask spread tidak berpengaruh signifikan terhadap holding period saham perusahaan yang tercatat ke dalam indeks LQ45 periode 2014-2016.

Bagi seorang investor selisih antara bid price dan ask price akan sangat mempengaruhi lamanya investor dalam melakukan holding period aset yang dimilikinya. Bid-ask spread pada penelitian ini menggunakan harga terendah (bid) dan harga tertinggi (ask). Oleh karena itu, variabel bid-ask spread tidak dapat menjelaskan variabel holding period saham. 
Penelitian ini mendukung penelitian terdahulu yaitu penelitian yang dilakukan oleh Dinar Ayu Nurwani (2012) hasil penelitiannya menunjukkan nilai $\mathrm{t}$ hitung sebesar 1,368 dengan signifikansi lebih besar dari tingkat signifikansi $(0,177>0,05)$ sehingga Ho diterima yang mengartikan tidak ada pengaruh bid-ask spread terhadap holding period saham.

a. Pengaruh market value terhadap holding period saham

Hasil uji t untuk variabel market value memiliki nilai t hitung sebesar 2,469 dan diperoleh nilai signifikansi sebesar 0,000. Nilai signifikansi lebih kecil dari tingkat signifikansinya $(0,000<0,05)$. Hasil penelitian ini dapat disimpulkan bahwa market value berpengaruh signifikan terhadap holding period saham perusahaan yang tercatat ke dalam indeks LQ45 periode 2014-2016.

Perusahaan dengan market value tinggi dinilai sebagai perusahaan yang besar sehingga dianggap memiliki kestabilan keuangan yang lebih tinggi dari perusahaan lain, mampu menghasilkan laporan dan informasi keuangan akurat yang akan mengurangi perbedaan antara pengharapan investor dengan yang sebenarnya terjadi di perusahaan. Sehingga jika suatu market value di sebuah perusahaan tinggi investor cenderung melakukan holding period saham lebih lama. Penelitian ini mendukung penelitian Dinar Ayu Nurwani (2012) yang menyimpulkan bahwa market value memiliki pengaruh signifikan terhadap holding period [9].

b. Pengaruh volume perdagangan terhadap holding period saham

Hasil uji $t$ untuk variabel volume perdaganganmemilikinilaithitungsebesar 2,627 dan diperoleh nilai signifikansi sebesar 0,005. Nilai signifikansi lebih besar dari tingkat signifikansinya $(0,005$ $<0,05)$. Hasil penelitian ini dapat disimpulkan bahwa volume perdagangan berpengaruh signifikan terhadap holding period saham perusahaan yang tercatat ke dalam indeks LQ45 periode 2014 -2016. Jika volume perdagangan suatu perusahaan meningkat maka perusahaan tersebut dapat dikatakan liquid.

Jika volume perdagangan tinggi investor pasti akan membeli saham dengan harga lebih tinggi, karena volume perdagangan yang tinggi menandakan bahwa saham tersebut aktif ditransaksikan di lantai bursa. Ketika volume perdagangan tinggi, investor berasumsi bahwa perusahaan tersebut sedang dalam kondisi yang baik. Maka, semakin tinggi pula dealer berkesempatan untuk mengambil keuntungan dari harga bid dan harga ask.

c. Pengaruh variance return terhadap holding period saham

Hasil uji $t$ untuk variabel variance return memiliki nilai $t_{\text {hitung }}=0,706$ dengan probabilitas sebesar 0,483 . Nilai signifikansi lebih besar dari tingkat signifikansi yang digunakan $(0,483>$ $0,05)$, hal ini menunjukkan $t_{\text {hitung }}<t_{\text {tabel }}$ sehingga $\mathrm{Ha}_{4}$ ditolak dan $\mathrm{Ho}_{4}$ diterima, dapat disimpulkan variance return tidak berpengaruh signifikan terhadap holding period saham perusahaan yang tercatat ke dalam indeks LQ45 periode 2014-2016.

Variance return merupakan ukuran langsung dari volatilitas saham perusahaan yang merupakan proksi dari resiko perusahaan yang disebabkan adanya fluktuasi harga saham, hal ini disebabkan karena investor pada perusahaan sampel cenderung menghindari resiko, sehingga memilih berinvestasi pada perusahaan yang memiliki variance of return rendah. Penelitian ini mendukung penelitian terdahulu yaitu penelitian yang dilakukan oleh Desy Ratnasari et al. (2012) hasil penelitiannya menunjukkan nilai t hitung variabel variance return lebih besar dari nilai signifikan $(2,277>0,005)$ sehingga Ho diterima yang mengartikan tidak ada pengaruh variance return terhadap holding period saham [10].

d. 4. Pengaruh dividen payout ratio terhadap holding period saham

Hasil uji $\mathrm{t}$ untuk variabel dividen payout ratio memiliki nilai $\mathrm{t}=-0,424$ dengan probabilitas sebesar 0,673. Nilai signifikansi lebih besar dari tingkat signifikansi yang digunakan $(0,673>$ $0,05)$, hal ini menunjukkan $t_{\text {hitung }}<t_{\text {tabel }}$ $\mathrm{Ha}_{5}$ ditolak dan $\mathrm{Ho}_{5}$ diterima, sehingga dapat disimpulkan dividen payout ratio tidak berpengaruh signifikan terhadap holding period saham perusahaan yang 
terdaftar ke dalam indeks LQ45 periode 2014-2016.

Dividen payout ratio merupakan gambaran seberapa besar dividen yang akan dibagikan perusahaan kepada pemilik saham dari total laba bersih yang diperoleh perusahaan. Semakin besar dividen payout ratio maka akan semakin mengguntungkan investor hal ini mengakibatkan investor memiliki saham dengan dividen payout ratio lebih tinggi akan cenderung melakukan holding period saham dalam jangka waktu relatif lebih lama agar terus memperoleh keuntungan yang tinggi dari investasi yang dilakukan investor. Akan tetapi variabel dividen payout ratio tidak berpengaruh signifikan terhadap holding period saham, yang mengartikan bahwa seluruh perusahaan yang tercatat ke dalam indeks LQ45 pada periode 20142016 tidak setiap tahun membagikan dividen kepada investor.

\section{SIMPULAN}

\section{Kesimpulan}

Berdasarkan hasil analisis data dan pengujian hipotesis yang telah dilakukan mengenai faktor-faktor yang mempengaruhi Holding period saham. Maka dapat ditarik kesimpulan sebagai berikut :

a. Tidak terdapat pengaruh Bid-ask spread terhadap holding period saham. Hal ini ditunjukkan dengan nilai t hitung sebesar $-0,824$ dan probabilitas sebesar 0,414 dan $d f=1,725$.

b. Terdapat pengaruh Market value terhadap holding period saham. Hal ini ditunjukkan dengan nilai t hitung sebesar 2,469 dengan probabilitas sebesar 0,000 dan $d f=1,725$.

c. Terdapat pengaruh Volume perdagangan terhadap holding period saham. Hal ini ditunjukkan dengan nilai t hitung sebesar 2,627 dengan probabilitas sebesar 0,005 dan $d f=1,725$.

d. Tidak terdapat pengaruh Variance return terhadap holding period saham. Hal ini ditunjukkan dengan hasil nilai $\mathrm{t}$ hitung sebesar 0,706 dengan probabilitas sebesar 0,483 dan $d f=1,725$.

e. Tidak terdapat pengaruh Dividen payout ratio terhadap holding period saham. Hal ini ditunjukkan dengan hasil nilai $\mathrm{t}$ hitung sebesar $-0,424$ dengan probabilitas sebesar 0,673 dan $d f=1,725$.

\section{Saran}

Berdasarkan hasil analisis pembahasan serta beberapa kesimpulan dan keterbatasan pada penelitian ini, adapun saran-saran yang dapat diberikan yaitu:

a. Bagi investor

Saran bagi investor sebaiknnya ketika akan melakukan investasi pada sebuah perusahaan, investor harus terlebih dahulu mengetahui informasi mengenai profil perusahaan. Investor wajib mengetahui informasi tingkat imbal hasil yang ditawarkan (return) dan tingkat risiko (risk).

b. Bagi Peneliti Selanjutnya

Disarankan untuk peneliti mendatang melakukan kajian ulang tentang faktorfaktor apa yang paling mempengaruhi keputusan investor dalam melakukan holding period saham.

\section{PUSTAKA}

[1] Afiffudin, I. 2014. Analisis Perbedaan Bid-Ask Spread Serta Pengaruh Return Saham, Earning Dan VolumePerdagangan Sagam TerhadapBid-Ask SpreadDi Sekitas Pengumuman Laporan Keuangan (Studi Empiris Perusahaan Sektor Industry Barang Konsumsi Yang Terdaftar Di Bursa Efek Indonesia Tahun 2010-2012). Bandung: Universitas Telkom.

[2] R. Desy, dan A. Dra Dewi, MM, 2014, Pengaruh Bid Ask Spread, Market Value, dan Variance Return Terhadap Holding Period CFP Program Manajemen, Surabaya: FINESTA. Vol. 2 No. 1, 2014, 99-102.

[3] Wisayang V.R.W. 2009. Analisis Pengaruh Bid-Ask Spread, Market Value, Dan Variance Retrun Saham Pada Saham LQ45 (Studi Empiris Periode Februari 2008-2009). Megister Manajemen Universitas Diponegoro. 
[4] P.D. Febrica, dan Y. Agung. 2014. Pengaruh Harga Saham, Volume Perdagangan, Likuiditas Dan Leverage Terhadap Bid-Ask Spread (Studi Pada Perusahaan Index Jii Di Bursa Efek Indonesia Periode Tahun 2010-2013). Semarang.

[5] Maulina, Vinus. 2009 Analisis Beberapa Faktor Yang Mempengaruhi Holding Period Saham Biasa Pada Perusahaan Go Public Yang Tercatat Dalam Index LQ45. WACANA. Vol. 12 No. 4.

[6] A. N Dinar, AR. Moch. Dzulkirom, dan Topowijono. 2012. Pengaruh Bid-Ask Spread, Market Value, Risk Of Return, Dan Dividend Payout Ratio Terhadap Holding Period Saham Biasa (Studi Pada Perusahaan Yang Tercatat Dalam Indeks LQ-45 Periode Tahun 2009-2011). Malang: Universitas Brawijaya.

[7] D.A. Lukman. 2013. Pengaruh Harga, Volume Perdagangan, Dan Volatility Saham Terhadap Bid-Ask Spread Saham Pada Indeks LQ45. Kindai Volume 9 Nomor 4. 